\title{
Antifungal effect of polymeric films containing the essential oil of Schinus terebinthifolius on Candida albicans biofilms
}

\author{
Efecto antifúngico de películas poliméricas \\ que contienen aceite esencial de Schinus terebinthifolius \\ en las biopelículas de Candida albicans
}

\author{
Hamdia A. Kassim¹, Karina Scheuermann², Alinne D. M. Gomes ${ }^{3}$, \\ Rubén D. Sinisterra ${ }^{4}$, Maria E. Cortés ${ }^{5} \square$
}

\begin{abstract}
${ }^{1}$ Dentistry Faculty, Universidade Federal de Minas Gerais (UFMG)
${ }^{2}$ Chemistry Department, ICEx, Universidade Federal de Minas Gerais (UFMG)

${ }^{3}$ Chemistry Department, ICEX, Universidade Federal de Minas Gerais (UFMG)

${ }^{4}$ Chemistry Department, ICEX, Universidade Federal de Minas Gerais (UFMG)

${ }^{5}$ Dentistry Faculty, Universidade Federal de Minas Gerais (UFMG)
\end{abstract}

Federal de Minas Gerais (UfmG), Dirección: Av. Antônio Carlos, 6627, 31270-901, Pampulha, Belo Horizonte - MG, Brazil. Teléfono: +55-31-34092419. Email: mecortes@ufmg.br

Received on: September 17, 2017 Revised on: October 15, $2017 \quad$ Available online: January 1, 2018

How to cite this article: Kassim H, Scheuermann K, Gomes A, Sinisterra R, Cortés M. Antifungal effect of polymeric films containing the essential oil of Schinus terebinthifolius on Candida albicans biofilms, Rev Nac Odontol. 2018;14(27), pp. 9 , enero 2018. doi: https://doi.org/10.16925/od.v14i27.2338

\begin{abstract}
Introduction: Candida albicans is a commensal microorganism in humans, that may cause oral candidiasis in people with immune deficiencies or ill-fitting dentures. C. albicans is becoming more resistant to drugs used in its treatment. This makes it necessary to develop new medicines that do not damage the host cells. There are many studies on the antimicrobial activity of leaves, stem and roots of Schinus terebinthifolius, but few studies attend its fruits. The aim of this study is to investigate the antifungal effect of polymeric films of hydroxypropyl methylcellulose (HPMC) containing the essential oil of the fruits of $S$. terebinthifolius against biofilms of $C$. albicans.

Materials and methods: The oil was prepared from the fruits of $S$. terebinthifolius and incorporated into polymeric films of HPMC using concentrations of $0.146,0.073$ e $0.037 \mathrm{~g} \cdot \mathrm{mL}^{-1}$. The minimum inhibitory concentration (Mic) was determined by micro dilution, wherein the minimum inhibitory concentration was $0.78 \%$. The antifungal effect of the films was tested using agar in petri dishes and acrylic resin blocks, both contaminated with C. albicans.
\end{abstract}

Results: The polymeric films containing essential oil had average inhibition zones of $24 \mathrm{~mm}, 21 \mathrm{~mm}$ and $20 \mathrm{~mm}$ for the concentrations $0.037,0.073$ and 0.146 g.mL-1, respectively.

Conclusion: The treated resin blocks showed no fungal growth afterwards, with the exception of the control blocks. The use of antimicrobial films containing natural products like $S$. terebinthifolius in the treatment of diseases such as oral candidiasis associated to prosthetic seems promising and with a decreased possibility of side effects.

Keywords: candidiasis, biological products, antifungal agents, oils, anacardiaceae, microbial sensitivity tests, dentures. 


\title{
Efecto antifúngico de películas poliméricas que contienen aceite esencial de Schinus terebinthifolius en las biopelículas de Candida albicans
}

\begin{abstract}
Resumen
Introducción: Candida albicans es un microorganismo comensal en humanos que puede causar candidiasis oral en personas con deficiencias inmunitarias o dentaduras mal ajustadas. C. albicans se está volviendo más resistente a los medicamentos utilizados para su tratamiento. Esto hace que sea necesario desarrollar nuevos medicamentos que no dañen las células huésped. Existen muchos estudios sobre la actividad antimicrobiana de hojas, tallo y raíces de Schinus terebinthifolius, pero pocos estudios se centran en sus frutos. El objetivo de este estudio es investigar el efecto antifúngico de las películas poliméricas de hidroxipropilmetilcelulosa (HPMc) que contiene el aceite esencial de los frutos de $S$. terebinthifolius en biopelículas de $C$. albicans.

Materiales y métodos: el aceite se preparó a partir de los frutos de $S$. terebinthifolius y se incorporó en películas poliméricas de HPMc con concentraciones de 0,146, 0,073 y 0,037 g.mL-1. La concentración mínima inhibitoria (mic) se determinó mediante microdilución, cuya concentración inhibitoria mínima fue de 0,78\%. El efecto antifúngico de las películas se probó con agar en placas de Petri y bloques de resina acrílica, ambos de ellos contaminados con C. albicans.

Resultados: las películas poliméricas que contenían aceite esencial presentaron zonas de inhibición promedio de $24 \mathrm{~mm}, 21 \mathrm{~mm}$ y $20 \mathrm{~mm}$ para las concentraciones $0,037,0,073$ y 0,146 g.mL-1, respectivamente.

Conclusión: los bloques de resina tratados no mostraron crecimiento fúngico posterior, con la excepción de los bloques de control. El uso de películas antimicrobianas que contienen productos naturales como S. terebinthifolius en el tratamiento de enfermedades como la candidiasis oral asociada a la prótesis parece prometedor y con menor posibilidad de que se desarrollen efectos secundarios.
\end{abstract}

Palabras clave: candidiasis, productos biológicos, agentes antifúngicos, aceites, anacardiaceae, pruebas de sensibilidad microbiana, dentaduras.

\section{Efeito antifúngico de filmes poliméricos que contêm óleo essencial de Schinus terebinthifolius nos biofilmes de Candida albicans}

\section{Resumo}

Introdução: Candida albicans é um microrganismo comensal em humanos que pode causar candidíase oral em pessoas com deficiências imunológicas ou próteses mal ajustadas. C. albicans está se tornando mais resistente aos medicamentos usados, pelo qual é necessário desenvolver uns novos que não prejudiquem as células hospedeiras. Existem muitos estudos sobre a atividade antimicrobiana de folhas, caules e raízes de Schinus terebinthifolius, mas poucos estudos consideram seus frutos.

Objetivo: investigar o efeito antifúngico dos filmes poliméricos de hidroxipropilmetilcelulose (HPMC) contendo o óleo essencial dos frutos de $S$. terebinthifolius em biofilmes de $C$. albicans.

Materiais e métodos: preparou-se o óleo a partir dos frutos de $S$. terebinthifolius e incorporou-se em filmes poliméricos de HPMc com concentrações de 0,146, 0,073 e 0,037 g.mL-1. A concentração inibitória mínima (cIM) foi determinada através de microdiluição, cuja concentração inibitória mínima foi de 0,78\%. 0 efeito antifúngico dos filmes foi testado com ágar em placas de Petri e blocos de resina acrílica, ambos contaminados com C. albicans. Resultados: os filmes poliméricos contendo óleo essencial apresentaram zonas de inibição médias de 24 mm, 21 mm e 20 mm para as concentrações 0,037, 0,073 e 0,146 g.mL-1, respectivamente.

Conclusão: os blocos de resina não apresentaram crescimento fúngico posterior, com exceção dos blocos de controle. 0 uso de filmes antimicrobianos contendo produtos naturais, tais como $S$. terebinthifolius, parece promissor para 0 tratamento de doenças como a candidíase oral associada à prótese. Estes filmes reduzem a possibilidade de desenvolvimento de efeitos colaterais.

Palavras-chave: candidíase, produtos biológicos, antifúngicos, óleos, anacardiaceae, testes de sensibilidade aos antimicrobianos, próteses. 


\section{Introduction}

Candidiasis is the most common fungal disease in humans. Amongst the Candida species, Candida albicans is the most frequent in the oral cavity. In the past, candidiasis was considered only an opportunistic infection, which affected patients debilitated by other diseases. However, today it is known that oral candidiasis can occur in relatively healthy people as a result of a complex interaction between host and microorganism [1]. Oral candidiasis is becoming prevalent in immunocompromised patients, [2] as well as in patients with ill-fitting dentures, and this occurrence has been strongly associated with denture-related stomatitis. Denture stomatitis is known to have a multifactorial etiology, but the presence of the fungi $C$. albicans is always strongly associated with it $[3,4]$.

Dentures have been used by some populations in a time range of 25 to 48 months and present some difficulties to maintain: level of education and motivation are correlated with older adult population [5]. Even so, these are important predisposing factors of candida contamination because the acrylic has microporosities, most of which usually could cause candidiasis when associated with suboptimal hygiene, acting as reservoirs of infections due to their porous nature [6]. It is believed that the ability of Candida spp., especially C. albicans, to adhere to acrylic surfaces may be important in the pathogenesis of the disease as adherence is apparently the initial step in microbial colonization and subsequent invasion of host surfaces.

Although diverse antifungal agents for the treatment of candidiasis have been used, failure of therapy is commonly found. The efficacy of treatment is dependent upon many factors such as the saliva and the cleansing action of the oral muscles. Thus, the therapeutic dose of antimicrobial agents does not reach the effective therapeutic concentration. In this manner, patients experience only a subtherapeutic antifungal concentration during treatment and the concentration of the drug may vary in different niches of the mouth. [7]

Due to the limited range of synthetic antifungal drugs available, coupled with $C$. albicans increase in drug resistance, as well as collateral effects experienced by some patients, some Brazilian plants claimed to have medicinal properties and over the past few years, they have been and are still being studied to determine their possible antimicrobial properties. The essential oil extracted from some of these medicinal plants as well as the extract derived from Schinus terebinthifolius have been tested against some clinically relevant fungi, including Candida species, and antifungal activity has been reported against the microorganisms tested $[8,9]$.

The Anacardiaceae family comprises more than 76 genera and 600 species with the genera Schinus, $[10,11]$ being the most studied. It is native to South America and found mainly on the coast of Brazil. [12] Schinus genus includes about 29 species, [13] and the main species are S. terebinthifolius and S. molle. The essential oil of this plant is concentrated mostly in the fruits [14] and its properties are attributed to the presence of high levels of monoterpenes [15]. S. terebinthifolius is used in folk medicine (alternative), with experimentally proven effects such as healing, anti-inflammatory, antipyretic, antiseptic (bactericidal and bacteriostatic), anti-allergic, anti-fungal, analgesic effects, purifying agent and hemostatic as well. It has also been used to treat sexually transmitted diseases, uterine inflammation, urinary and respiratory tract infections, skin ulcers, rheumatism and gastrointestinal disorders [16-22]. Many parts of this plant such as the bark, leaves, roots and fruits have been studied, as well as various antimicrobial properties, which have been reported for many microorganisms such as Candida spp., Botrytis spp. and Staphylococcus spp. [23-26].

The aim of this study was to evaluate the antifungal properties of polymeric films of hydroxypropyl methylcellulose containing the essential oil of Schinus terebinthifolius against biofilms of Candida albicans.

\section{Materials and methods}

\section{S. terebinthifolius essential oil extraction}

Because S. terebinthifolius is a native plant and due to the difficulty in finding producers, we chose to always buy the pepper samples from the same distributor. The extraction of the essential oil was done by the hydrodistillation method. The fruits were grinded and placed in dichloromethane 
$\left(\mathrm{CH}_{2} \mathrm{Cl}_{2}\right)$ for five days to extract the oil. After this period, the mixture was brought to a rotary evaporator at a temperature of $40{ }^{\circ} \mathrm{C}$ to evaporate the dichloromethane, thereby yielding the pure essential oil which prevents the loss of compounds sensitive to high temperatures [27].

\section{Determination of the Minimum Inhibitory Concentration}

The minimum inhibitory concentration (MIC) was determined following guidelines from the Clinical and Laboratory Standards Institute. [28] C. albicans strains (ATCC 18804) were incubated in Sabouraud Dextrose broth at $34^{\circ} \mathrm{C}$ in aerobic conditions for $24 \mathrm{~h}$. After that, the incubated strains were diluted with $0.9 \%$ sterile saline solution to obtain an inoculum of $10^{8} \mathrm{CFU} / \mathrm{mL}$ and dispersed into a 96 well plate containing Sabouraud Dextrose broth. With an initial concentration of $0.072 \mathrm{~g}$. $\mathrm{mL}^{-1}$ of the S. terebinthifolius essential oil, a serial dilution was made in triplicate. A negative control was made using only Sabouraud broth; while a positive control was made using Sabouraud broth and the inoculum of $C$. albicans strains, to ascertain the viability of the fungi strains as well as to use it as a standard for comparison. The plates were incubated for $24 \mathrm{~h}$ in aerobic conditions at $34{ }^{\circ} \mathrm{C}$; this was defined as the minimum inhibitory concentration in absence of fungal growth.

\section{Polymeric films of HPMC containing the essential oil of S. terebinthifolius formation}

Three concentrations of the S. terebinthifolius essential oil were used to make the HPMC films: $0.146,0.073$ and 0.037 g.mL $\mathrm{m}^{-1}$. For example, to make an HPMC film containing a concentration of $0.146 \mathrm{~g}$. $\mathrm{mL}^{-1}$ S. terebinthifolius essential oil, $0.3 \mathrm{~g}$ of the powder of HPMC were dissolved in a total volume of $5 \mathrm{~mL}$ of distilled water (75\%) and propylene glycol (25\%). $5 \mathrm{~mL}$ of the pure essential oil of S. terebinthifolius and $20 \mu \mathrm{L}$ of citric acid, a conservative, were added to the solution and mixed thoroughly while being heated at a temperature of $60{ }^{\circ} \mathrm{C}$ for 30 minutes. A control film was made by dissolving $0.3 \mathrm{~g}$ of HPMC powder into $7.5 \mathrm{~mL}$ of distilled water, $2.5 \mathrm{~mL}$ of propylene glycol and $20 \mu \mathrm{L}$ of citric acid. All concentrations were mixed for about 30 minutes at a temperature of $60{ }^{\circ} \mathrm{C}$ after which the mixtures were poured into petri dishes and allowed to dry at a temperature of $37^{\circ} \mathrm{C}$ for $24 \mathrm{~h}$. The dried films were then cut into square pieces of dimensions $4 \times 4 \mathrm{~mm}$ each.

\section{Antifungal test using polymeric films of HPMC containing $S$. terebinthifolius essential oil}

Strains of C. albicans were previously cultivated a day before and adjusted to an inoculum of $10^{8} \mathrm{CFU} /$ $\mathrm{mL} .100 \mu \mathrm{L}$ of this inoculum was spread on different petri dishes containing Sabouraud Dextrose Agar each, in sixplicate. The HPMC films with the different concentrations of the essential oil of $S$. terebinthifolius previously prepared, and the control films were placed on the three contaminated agar surfaces, each petri dish containing the four different films. The dishes were incubated for $24 \mathrm{~h}$ in aerobic conditions at $34^{\circ} \mathrm{C}$. The inhibition zone was defined as the largest diameter, the mean of the data was determined and the results were evaluated applying Kruskal-Wallis test.

\section{Antifungal test using polymeric films of HPMC containing essential oil of S. terebinthifolius in resin blocks}

The antifungal activity of the films was also tested using acrylic resin blocks previously contaminated with strains of C. albicans. Strains of C. albicans were initially incubated in Sabouraud Dextrose broth in aerobic conditions at $34^{\circ} \mathrm{C}$ for $24 \mathrm{~h}$. After $24 \mathrm{~h}$, sterilized square acrylic resin blocks of size $6 \times 6 \times 4 \mathrm{~mm}$ were placed into the test tube containing the already cultivated strains of $C$. albicans. Enough Sabouraud Dextrose broth was added to the test tube to cover all the blocks. The content of the test tube was homogenized and the test tube was incubated for another $24 \mathrm{~h}$. Following those $24 \mathrm{~h}$, each contaminated acrylic resin block was washed gently with sterile saline solution to remove unattached strains while not disturbing the biofilm formed around the blocks.

These blocks were covered on every side with the polymeric films containing the different concentrations of S. terebinthifolius, stored in Sabouraud Dextrose broth and incubated for $24 \mathrm{~h}$ in aerobic conditions at $34{ }^{\circ} \mathrm{C}$. Each concentration was coated around three different contaminated acrylic 
resin blocks. The control films were coated around three contaminated blocks and three sterilized blocks each. After $24 \mathrm{~h}$, the blocks were removed from the films and placed in a different sterile test tube containing Sabouraud Dextrose broth and incubated for another $24 \mathrm{~h}$ in aerobic conditions at $34^{\circ} \mathrm{C}$.

After the $24 \mathrm{~h}$, the blocks were each placed gently in sterile test tubes containing sterile saline solution. The blocks were placed in an ultrasonic machine for 10 minutes to shake off the unattached fungal strains. Afterwards, blocks were placed on petri dishes containing sterile Sabouraud Dextrose Agar and incubated for $24 \mathrm{~h}$ at $34^{\circ} \mathrm{C}$ in aerobic conditions to check for fungal growth.

\section{Citotoxicity study}

3T3-L1 cells (murine fibroblast) were cultured in DMEm (Dulbecco's Modified Eagle Medium) high glucose supplemented with 10\% FBs (fetal bovine serum) and $1 \%$ antibiotic / antimycotic solution. These cells were maintained in an incubator at $37^{\circ} \mathrm{C}$ with $5 \% \mathrm{CO}_{2}$.

Polymeric HPMC films containing the essential oil in three concentrations were used to obtain the eluates. To achieve this, the HPMC films with dimensions of $4 \times 4 \mathrm{~mm}$ were put into culture medium each (the same used for the cultivation of the cells to be tested). The supernatant was collected after $24 \mathrm{~h}$ of its release in an incubator at $37{ }^{\circ} \mathrm{C}$ with $5 \% \mathrm{CO}_{2}$. This material was kept frozen in a $-20^{\circ} \mathrm{C}$ freezer until the completion of the cell cytotoxicity assays.

The treatments were distributed in triplicate in serial dilutions starting from a 1:1 dilution totaling 18 points, only dilutions with significant results are represented graphically. The treatments lasted for $24 \mathrm{~h}$ and the assessment of cellular cytotoxicity was performed using the MTT colorimetric assay according to the manufacturer's recommendations. The readings of the plates were made by a reader at a wavelength of $570 \mathrm{~nm}$. The construction of graphs and statistical analysis were performed with the aid of GraphPad Prism 6. The results were expressed as mean \pm standard error of the mean and compared with the control groups. Analysis of variance were performed, one-way ANOva followed by Tukey's as a post-test, the differences were considered significant at $\mathrm{p}<0.05$.

\section{Results}

Essential oil extraction of S. terebinthifolius and Minimum Inhibitory Concentration

In this study, the antifungal activity of the essential oil obtained from the fruits against $C$. albicans, using dichloromethane as a solvent, was observed. The minimum inhibitory concentration found in this study was $0.0078 \mathrm{~g} / \mathrm{mL}$.

\section{Antifungal test using polymeric films of HPMC containing the essential oil of S. terebinthifolius}

All the polymeric films of HPMC containing the different concentrations of the essential oil of $S$. terebinthifolius had an inhibitory effect on C. albicans strains. However, the 0.146 g.mL $\mathrm{m}^{-1}$ concentration was the most significatively active (Table 1).

Table 1. Inhibition zones after placing the polymeric films of HPMC containing the different concentrations of essential oil of Schinus terebinthifolius against C. albicans.

\begin{tabular}{cc}
\hline $\begin{array}{c}\text { Polymeric films with different } \\
\text { concentrations of essential oil }\end{array}$ & Inhibition zones \\
\hline 0.146 g.mL-1 & $25 \pm 1.2 \mathrm{~mm}^{*}$ \\
0.073 g.mL $\mathrm{mL}^{-1}$ & $21 \pm 1.7 \mathrm{~mm}$ \\
0.037 g.mL $\mathrm{mL}^{-1}$ & $20 \pm 0.7 \mathrm{~mm}$ \\
\hline
\end{tabular}

* Statistical difference $(\mathrm{p}<0.05)$

Source: own work

\section{Antifungal films inhibition of HPMC containing the essential oil of $S$. terebinthifolius in association with contaminated acrylic resin blocks}

None of the acrylic resin blocks contaminated with the strains of $C$. albicans had any fungal growth after they were treated with the polymeric films of $S$. terebinthifolius, washed with saline solution and incubated on Sabouraud Dextrose Agar for 24 h. Only the control blocks, which have not been treated with the polymeric films containing the essential oil, showed fungal growth. 


\section{Cytotoxicity assay}

The cytotoxicity of polymeric films of HPMC containing the different concentrations of the essential oil of S. terebinthifolius was evaluated by cell viability assay. The fibroblasts maintained cell viability above $50 \%$ in dilution 1:64 in the concentration of 0.146 g.mL-1, in dilution 1:32 in the concentration of 0.073 g.mL- 1 and in dilution 1:16 in the concentration of 0.037 g.mL -1 (Fig. 1). The 0.037 g.mL -1 in dilution 1:16 was not cytotoxic and the difference was significant in relation to the other two groups analyzed $\left({ }^{*} \mathrm{p}<0.05\right)$.

\section{Discussion}

There are many studies about the antifungal effect of the essential oils from the leaves, bark [29] and roots of S. terebinthifolius. Johann et al. [30] showed that the leaves of $S$. terebinthifolius were able to inhibit the growth of three different strains of C. albicans isolated from the mouth of patients with denture related stomatitis, with the MIC showing to be $7.81 \mathrm{~g} / \mathrm{mL}$. Johann et al. [31] then noted that the MIC of the essential oil of the leaves and bark of $S$. terebinthifolius against three strains of $P$. brasiliensis was $30 \mu \mathrm{g} / \mathrm{mL}$ for all the strains tested. Alves et al. [29] had a MIC of $0.3125 \mathrm{~g} / \mathrm{mL}$ against C. albicans using the tincture from the bark of $S$. terebinthifolius. However, there are very few studies about the antifungal effect of the essential oil from its fruits.

In this study, an antifungal activity of the essential oil obtained from the fruits was found against C. albicans using dichloromethane as a solvent. This result contrasts the results of a study by Degáspari et al. [32] where the alcoholic and aqueous extract of the fruits of $S$. terebinthifolius were tested against some microorganisms including $C$. albicans and inhibition zones were only observed with the alcoholic extract against two bacteria only. Neither the alcoholic nor the aqueous extract in that study exhibited any antifungal activity against C. albicans. The antifungal activity encountered in our study could be due to differences in both the strains of fungi and fruits used, since composition of the fruits especially vary in accordance with many factors, such as the place and season of harvest. Our positive results may have also been due to the polymeric films of HPMC used in our study,

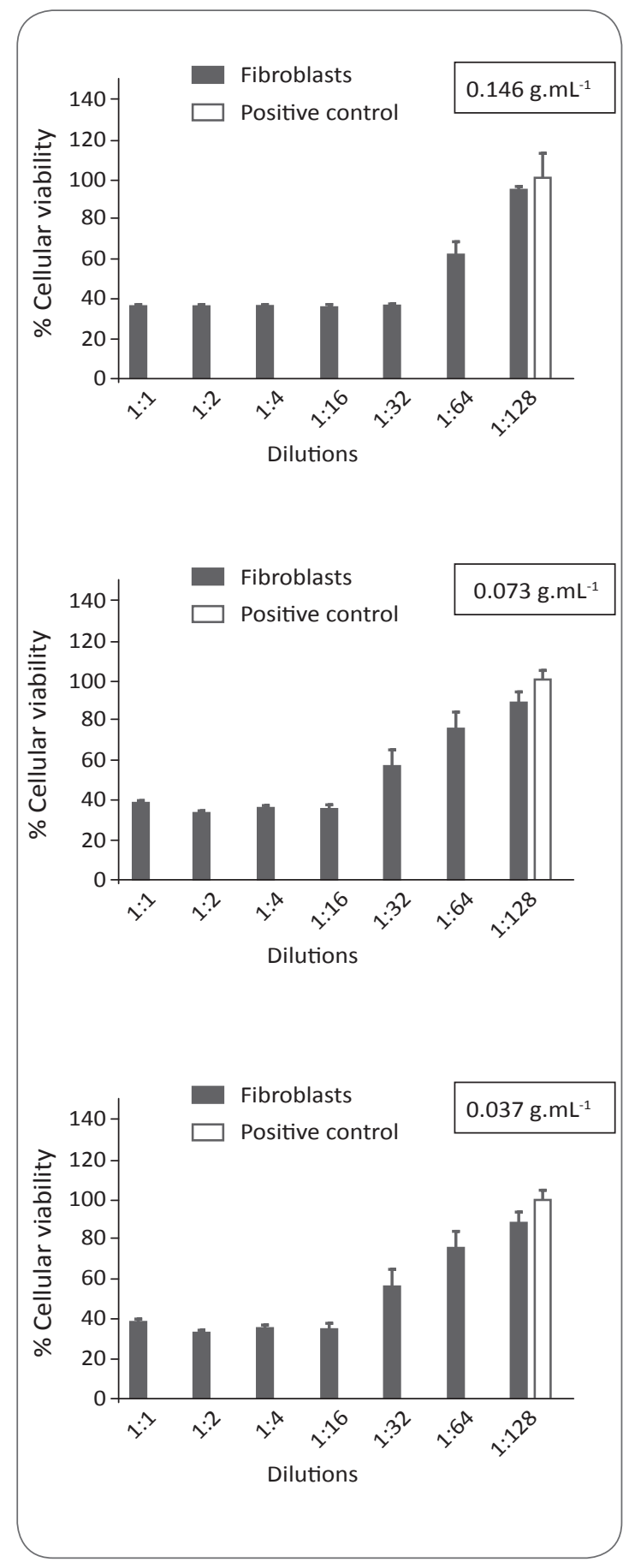

Figure 1. Cytotoxicity effect of eluate of HPMC films containing essential oil from mature fruits of $S$. terebinthifolius in concentrations of 0.146 g.mL $L^{-1}, 0.073$ g.mL $L^{-1}, 0.037$ g.mL $L^{-1}$ in 3T3-L1 fibroblasts $\left({ }^{*} \mathrm{p}<0.05\right)$.

Source: own work 
which ensured a slow, prolonged and steady liberation of the active compounds of the essential oil, exposing the fungi to it for a long period.

Oliveira et al. [23] tested the antifungal activity of the essential oil of the fruits of S. terebinthifolius against Colletotrichum gloeosporioides and an inhibition of $79.07 \%$ of the fungal growth was noted using a concentration of $0.5 \%$. In addition, it was also noted that the higher the concentration, the higher the inhibition of fungal growth. Our study proved the opposite with the greatest inhibition of fungal growth occurring with the lowest concentration used which was $12.5 \%$. These results further demonstrate that the essential oil of S. terebinthifolius in conjunction with the polymeric films of HPMC does have an antifungal effect against biofilms of C. albicans.

Some reasons for the popularity of HPMC for extended release coatings, are that the water-soluble HPC may act as a pore former, [33] soluble in water and able to accommodate high levels of drug loading. Moreover, the variations in processing show little effect on component composition [34]. Due to the oil's viscosity, getting a homogenous solution most of the time proved difficult. All the same, the results from this study proved promising since the use of the polymeric films helped maintaining a steady supply of the active compounds from the essential oil, ensuring that the oil was in contact with the fungi for a prolonged period.

\section{Conclusion}

This study proved that the polymeric films containing the essential oil were able to inhibit the growth of the strains of $C$. albicans, as well as the biofilms attached to the contaminated acrylic resin blocks, showing to be a promising method for treating denture-related Candidiasis, considering the antifungal activity of this plant as well as its vast availability in nature.

\section{Acknowledgements}

The authors would like to acknowledge the financial support of the following Brazilian Research agencies: INCT-Nanobiofar (CNPq/MCT/FAPEMIG), Conselho Nacional de Desenvolvimento Científico e Tecnológico (CNPq), Coordenação de Aperfeiçoamento de Pessoal de Nível Superior (CAPEs),
Fundação de Amparo à Pesquisa do Estado de Minas Gerais (FAPEMIG).

\section{References}

[1] Sholapurkar AA, Pai KM, Rao S. Comparison of efficacy of fluconazole mouthrinse and clotrimazole mouthpaint in the treatment of oral candidiasis. Aust Dent J. 2009;54:341-6. doi: http://dx.doi.org/10.1111/j.1834-7819.2009.01160.x

[2] Burgers R, Hhnel S, Reichert TE, Rosentritt M, Behr M, Gerlach T, et al. Adhesion of Candida albicans to various dental implant surfaces and the influence of salivary pellicle proteins. Acta Biomater. 2010;6:2307-313. doi: http://dx.doi.org/10.1016/j. actbio.2009.11.003

[3] Shulman JD, Rivera-Hidalgo F, Beach MM. Risk factors associated with denture stomatitis in the United States. J Oral Pathol Med. 2005;34:340-6. doi: http:// dx.doi.org/10.1111/j.1600-0714.2005.00287.x

[4] Figueiral MH, Azul A, Pinto E, Fonseca PA, Branco FM, Scully C. Denture-related stomatitis, identification of etiological and predisposing factors a large cohort. J Oral Rehabil. 2007;34:448-55. doi: http:// dx.doi.org/10.1111/j.1365-2842.2007.01709.x

[5] Gómez-Pino MF, Silva-Ríos MA, Páez-Herrera MC, Gómez-Ortega J, Zea-Restrepo FJ, Agudelo Suárez AA. Salud bucal y factores relacionados en pacientes portadores de prótesis bimaxilar en una institución docencia servicio de Medellín, Colombia. Rev Nac Odontol. 2017;13(24):65-77. doi: https:// doi.org/10.16925/od.v12i24.1662. Available from: https://revistas.ucc.edu.co/index.php/od/article/ view/1662

[6] Parvinen T. Stimulated salivary flow rate, $\mathrm{pH}$ and Lactobacillus and yeast concentrations in persons with different types of dentition. Scand J Dent Res. 1984;92:412-18. doi: http://dx.doi.org/10.1111/j.1600-0722.1984.tb00910.x

[7] Nevzatoğlu EU, Ozcan M, Kulak-Ozkan Y, Kadir T. Adherence of Candida albicans to denture base acrylics and silicone-based resilient liner materials with different surface finishes. Clin Oral Investig. 2007;11(3):231-6. doi: https://doi.org/10.1007/ s00784-007-0106-3

[8] Johann S, Pizzolatti MG, Donnici CL, Resende MA. Antifungal properties of plants used in Brazilian traditional medicine against clinically relevant fungal pathogens. Braz J Microbiol. 2007;38:632-7. doi: https://doi.org/10.1590/s1517-83822007000400010

[9] Lima MRF, Luna JS, Santos AF, Andrade MCC, Sant ' Ana AEG, Genetj J, et al. Anti-bacterial activity of some Brazilian medicinal plants. J Ethnopharmacol. 
2006; 105:137-47. doi: http://dx.doi.org/10.1016/j. jep.2005.10.026

[10] Corrêa MP, Pena LA. Dicionário de plantas úteis do Brasil e das exóticas cultivadas. Rio de Janeiro: Ministério da Agricultura, Instituto Brasileiro de Desenvolvimento Florestal; 1984.p. 1874-1934

[11] Correia SJ, David JP, David JM. Metabólicos secundários de espécies de Anacardiaceae. Quim Nova. 2006;29:1287-300. doi: https://doi.org/10.1590/ s0100-40422006000600026

[12] Barbosa LCA, Demuner AJ, Clemente AD, Paula VF, Ismail FMD. Seasonal variation in the composition of volatile oils from Schinus terebinthifolius Raddi. Quim Nova. 2007;30:1959-965. doi: https://doi. org/10.1590/S0100-40422007000800030

[13] Carvalho MG, Melo AGN, Aragão CFS, Raffin FN, Moura TFAL. Schinus terebinthifolius Raddi: chemical composition, biological properties and toxicity. Rev Bras Plantas Med. 2013;15(1):158-169. doi: https://doi.org/10.1590/S1516-05722013000100022

[14] Bendaoud H, Romdhane M, Souchard JP, Cazaux S, Bouajila J. Chemical composition and anticancer and antioxidant activities of Schinus molle L. and Schinus terebinthifolius Raddi berries essential oils. J Food Sci. 2010;75:466-72. doi: https://doi.org/10.1111/j.1750-3841.2010.01711.x

[15] Azevedo CF, Quirino ZGM, Bruno RLA. Estudo farmacobotânico de partes aéreas vegetativas de aroeira-vermelha (Schinus terebinthifolius Raddi, Anacardiaceae). Rev Bras Plant Med, 2015:17(1),2635. Mar. https://doi.org/10.1590/1983-084x/11_090

[16] Coutinho HI, Lopes OLS, Torres OMJ, Matias JEF, Coelho JCU, Stahlke JHJ, et al. Schinus terebinthifolius Raddi and it's influence in the healing process of colonic anastomosis. Experimental study in rats. Acta Cir Bras. 2006;21:9-54. http://dx.doi. org/10.1590/S0102-86502006000900008

[17] Santos EB, Dantas GS, Santos HB, Diniz MFF, Melo, Sampaio FC. Estudo etnobotânico de plantas medicinais para problemas bucais no município de João Pessoa, Brasil. Rev Bras Farmacog. 2009;19(1b):321-4. https://doi.org/10.1590/S0102695X2009000200024

[18] Enioutina EY, Salis ER, Job KM, Gubarev MI, Krepkova LV, Sherwin CM. Herbal Medicines: challenges in the modern world. Part 5. status and current directions of complementary and alternative herbal medicine worldwide. Expert Rev Clin Pharmacol. 2017 Mar;10(3):327-38. doi: https://doi.org/ 10.1080/17512433.2017.1268917.

[19] Schmourlo G, Mendonça-Filho RR, Alviano CS, Costa SS. Screening of antifungal agents using etanol precipitation and bioautography of medicinal and food plants. J Ethnopharmacol. 2005;96:563-8. doi: https://doi.org/10.1016/j.jep.2004.10.007

[20] Medeiros KCP, Monteiro JC, Diniz MFFM, Medeiros IA, Silva BA, Piuvezam MR. Effect of the activity of the Brazilian polyherbal formulation, Eucalyptus globulus Labill, Peltodon radicans Pohl and Schinus terebinthifolius Raddi in inflammatory models. Rev Bras Farmacogn. 2007;17:23-8. doi: https://doi. org/10.1590/S0102-695X2007000100006

[21] Cavalher-Machado SC, Rosas EC, Brito FA, Heringe AP, Oliveira RR, Kaplan MA, Figuet al. The antiallergic activity of the acetate fraction of Schinus terebinthifolius leaves in IgE induced mice paw edema and pleurisy. Int Immunopharmacol. 2008; 8:1552-60. doi: https://doi.org/10.1016/j.intimp.2008. 06.012

[22] Pereira EM, Gomes RT, Freire NR, Aguiar EG, Brandão MG, Santos VR. In vitro antimicrobial activity of Brazilian medicinal plant extracts against pathogenic microorganisms of interest to dentistry. Planta Med. 2011;77:401-4. doi: https://doi.or$\mathrm{g} / 10.1055 / \mathrm{s}-0030-1250354$

[23] Oliveira Junior LFG, Santos RB, Reis FO, Matsumoto ST, Bispo WMS, Machado, LP et al. Efeito fungitóxico do óleo essencial de aroeira da praia (Schinus terebinthifolius RADDI) sobre Colletotrichum gloeosporioides. Rev Bras Pl Med. 2013;15:150-7. doi: https://doi.org/10.1590/S1516-05722013000100021

[24] Silva AB, Silva T, Franco ES, Rabelo SA, Lima ER, Mota RA, et al. Antibacterial activity, chemical composition and cytotoxicity of leaf's essential oil from Brazilian pepper tree (Schinus terebinthifolius, RADDI). Braz J Microbiol. 2010;41:158-63. doi: https://doi.org/10.1590/s1517-83822010000100023

[25] Atti Dos Santos AC, Rossato M, Serafini LA, Bueno M, Crippa LB, Sartori VC, et al. Efeito fungicida dos óleos essenciais de Schinus molle L. e Schinus terebinthifolius Raddi, Anacardiaceae, do Rio Grande do Sul. Rev Bras Farmacogn. 2010;20:154-9. doi: https://doi.org/10.1590/S0102-695X2010000200003

[26] Lima MRF, Luna JS, Santos AF, Andrade MCC, Santana AEG, Genetj J, et al. Anti-bacterial activity of some Brazilian medicinal plants. J Ethnopharmacol. 2006;105:137-47. doi: https://doi.org/10.1016/j. jep.2005.10.026

[27] Johann S, Cisalpino P, Watanabe GA, Cota BB, Siqueira E, Pizzolatti MG, et al. Antifungal activity of extracts of some plants used in Brazilian traditional medicine against the pathogenic fungus Paracoccidioides brasiliensis. Pharm Biol. 2010; 48(4):388-96 doi: https://doi.org/10.3109/13880200903150385

[28] Clinical and Laboratory Standards Institute. Reference method for broth dilution antifungal susceptibility testing of yeasts; Approved Standard $3^{\text {rd }}$. ed. 
CLSI document M27-A3. Clinical and Laboratory Standards Institute Wayne, PA; 2008. p. 1-28

[29] Alves LA, Freires IA, Pereira TM, Souza A, Lima EO, Castro RD. Effect of Schinus terebinthifolius on Candida albicans growth kinetics, cell wall formation and micromorphology. Act Odontol Scand. 2013;71:965-71. doi: https://doi.org/10.3109/00016 357.2012.741694

[30] Johann S, Silva DL, Martins CVB, Zani CL, Pizzolatti MG, Resende MA. Inhibitory effect of extracts from Brazilian medicinal plants on the adhesion of Candida albicans to buccal epithelial cells. World J Microbiol Biotechnol. 2008;24:2459-64.doi: https:// doi.org/10.1007/s11274-008-9768-5

[31] Johann S, Sá NP, Lima LARS, Cisalpino PS, Cota BB, Alves TMA, et al. Antifungal activity of schinol and a new biphenyl compound isolated from Schinus terebinthifolius against the pathogenic fungus Paracoccidioides brasiliensis. Ann Clin Microbiol Antimicrob. 2010;9:30. doi: https://doi.org/10.1186/ 1476-0711-9-30
[32] Degáspari CH, Waszcynskyi N, Prado MRM. Antimicrobial activity of Schinus terebenthifolius Raddi. Cienc Agrotec. 2005;29:617-22. doi: https://doi. org/10.1590/S1413-70542005000300016

[33] Andersson H, Häbel H, Olsson A, Sandhagen S, von Corswant C, Hjärtstam J, et al. The influence of the molecular weight of the water-soluble polymer on phase-separated films for controlled release. Int J Pharm. 2016 Sep 10;511(1):223-35. doi: https://doi. org/10.1016/j.ijpharm.2016.06.058

[34] Viridén A, Wittgren B, Larsson A. Investigation of critical polymer properties for polymer release and swelling of HPMC matrix tablets. Eur J Pharm Sci. 2009;36:297-309. doi: https://doi.org/10.1016/j.ejps. 2008.10.021 